\title{
A rendetlenség terjedése ${ }^{1}$
}

\author{
BALÁZS ANDRÁS
}

Az alábbiakban Kees Keizer, Siegwart Lindenberg és Linda Steg „The Spreading of Disorder" (A rendetlenség terjedése) című kutatásának legfontosabb eredményeit igyekszem összefoglalni, reflektálva a tanulmány „zéró tolerancia” típusú büntetőpolitikákra vonatkozó tanulságaira. Recenzióm végén a vizsgálat alapjául szolgáló törött ablakok elméletével (broken windows theory) kapcsolatos néhány szakmai fenntartást szeretnék ismertetni.

\section{A kutatás tárgya}

A Science nevű tekintélyes tudományos folyóiratban megjelent tanulmány alapját képező vizsgálat arra a kérdésre keresi a választ, hogy a törött ablakok elméletében megfogalmazott törvényszerűségek bizonyíthatóak-e empirikus módon. A rendetlen környezet, illetve mások látható normasértése valóban további kihágásokra ösztönzi-e az embereket. A kutatók hat különböző terepkísérlettel kívánták tesztelni a népszerű elmélet gyakorlati megvalósulását, illetve a normasértések megsokszorozódása mögött álló szociálpszichológiai folyamatokat.

A törött ablakok elméletét két társadalomtudós, James Q. Wilson és George L. Kelling fogalmazta meg a nyolcvanas évek elején (Kelling - Wilson 1982). Ebben a cikkben a szerzők amellett érvelnek, hogy a normaszegő magatartásokra érkező társadalmi válaszreakció hiánya növeli a normasértő magatartás legitimitását, valamint a súlyosabb bűncselekmények terjedéséhez is vezethet.

Elméletük leírásához egy egyszerű hasonlatot használtak: amennyiben egy városrészben a betört ablakokat nem javítják ki, azok látványa azt az üzenetet közvetíti, hogy bárki szabadon megszegheti a szabályokat, akár súlyosabb módon is, mint az egyszerű vandalizmus. Ha viszont a betört ablakot azonnal kijavítják, akkor ennek az a társadalmi jelentése, hogy a közösség éberen őrködik a közös normák felett.

${ }^{1}$ Kees Keizer - Siegwart Lindenberg - Linda Steg (2008): The Spreading of Disorder, Science, Vol 322. https://www.influenceatwork.com/wp-content/uploads/2012/02/BrokenWindowsArticle.pdf (Utolsó letöltés: 2018.05.13)

${ }^{2}$ Tudományos segédmunkatárs, MTA Társadalomtudományi Kutatóközpont Szociológiai Intézet. 


\section{RECENZIÓ}

Bár Wilson és Kelling hipotézisét New York polgármestere és rendőrfőkapitánya a 90-es évek közepén az ún. „Életminőség kampány” (Quality of life campaign) keretében a gyakorlatban is alkalmazta, a kedvezően alakuló bűnözési statisztikák és a közrendvédelmi program összefüggéseit nem sikerült kétséget kizáróan bizonyítani.

\section{A kísérletek eredményei}

A kutatók a hat kontrollált terepkísérlet során elsősorban arra voltak kíváncsiak, hogy a megfelelő magatartásra felszólító (injunctive) norma és a mások magatartásáról informáló (descriptive) norma konfliktusa milyen mértékben befolyásolja a cselekvőket. Egyszerübben fogalmazva azt a kérdést tették fel, hogy abban az esetben, ha a definiált tiltást a környezet nagyobb része nem veszi figyelembe, miként változik meg a többi cselekvő szabályhoz való viszonya. A közös szabályok mások általi felrúgása növeli-e az egyén hedonista vagy haszonmaximalizáló ambícióját. A következő kísérletek a fenti felvetések mellett arra is választ igyekeztek találni, hogy a párhuzamos normasértések és az egyszerre fennálló rendezetlenség (disorder) növeli-e a vizsgálati alanyok normaszegő hajlamát. A kutatás tanulságainak levonása előtt röviden összefoglalom az egyes kísérletek eredményeit:

1. „Kerékpár parkoló kísérlet”

Az első kísérlet során egy szupermarket kerékpár parkolójában egy „Szemetelni tilos" táblát helyeztek először egy tiszta falfelületre, majd egy öszszegraffitizett falra. A kutatók arra voltak kíváncsiak, hogy az ott parkoló biciklikre ragasztott szórólapokat a tiszta és a graffitis környezetben milyen arányban dobják el. A nem graffitis esetben 33\% hagyta figyelmen kívül a tiltó tábla rendelkezését, míg a graffitis fal esetén a szemetelők aránya 69\%ra növekedett.

\section{2. „Kerítés kísérlet”}

A következő kísérlet során egy gépjármű parkoló kerítésén tátongó lyuk mellett két tiltó jelzést helyeztek el. Az egyik arra szólított fel, hogy tilos a lyukon belépni, a másik pedig a biciklik kerítéshez rögzítését tiltotta. A kutatók azt vizsgálták, hogy egy, a tilalom ellenére a kerítéshez láncolt kerékpár mennyiben befolyásolja a másik szabály betartását. A kísérlet során arra jutottak, hogy a tiltás ellenére leláncolt bicikli jelenlétében az arra járók 82\%a bújt át a kerítésen, míg a bicikli leláncolása hiányában csupán $27 \%$ sértette meg az átkelést tiltó normát. 


\section{RECENZIÓ}

3. „Bevásárlókocsi kísérlet”

Ebben a kísérletben azt vizsgálták, hogy a szupermarket gépjármű parkolójában a kocsik szélvédőjére ragasztott szórólapokat többen dobják-e el abban az esetben, hogyha a bevásárlókocsik a felszólításnak megfelelően vissza vannak tolva a helyükre, mintha széthagyva állnának a parkoló területén. A kísérlet eredménye szerint visszatolt bevásárló kocsik esetén az arra járók csupán 30\%-a dobta el a szórólapot, míg a rendezetlenül hagyott bevásárló kocsik környezetében 58\% szemetelt.

4. „Pályaudvar kísérlet”

Ebben az esetben a kutatók nem egy magán tiltást, hanem egy közismert törvényi szabályozást választottak a kísérlet kontextusául. Hollandiában szilveszter éjszakáját leszámítva az év többi napján tűzijáték, illetve petárda tilalom van érvényben. A vizsgálat arra vonatkozott, hogy egy pályaudvar bicikli parkolójában a kerékpárokra ragasztott szórólapokat a tiltott petárdázás hangjának hatására többen dobják-e el, mint nyugodt környezetben. A kísérlet eredményeként megállapították, hogy hallható petárda hang esetén a kísérlet alanyainak 80\%-a szemetelt, míg zajhatás hiányában csupán az emberek 52\%-a dobta el a kerékpárokra helyezett szórólapot.

\section{5. „Boríték kísérlet I.”}

Az ötödik kísérlet során ismét egy büntetőjogi tényállás szolgált a vizsgálat kereteként. A kutatók egy átlátszó borítékban található 5 eurós bankjegyet helyeztek el egy postaládában úgy, hogy tartalma felismerhető legyen. A kérdés pedig arra irányult, hogy összegraffitizett, illetve szemetes környezetben többen tulajdonítják-e el a borítékot, mint tiszta, rendezett viszonyok között. A vizsgálat eredménye rámutatott, hogy graffiti és szemét hiányában csupán az emberek 13\%-a lopta el a borítékot, míg graffitis és szemetes környezetben ugyanezt $27 \%$ tette meg.

\section{6. „Boríték kísérlet II.”}

Az 5. számú kísérlet folytatásaként a graffitis és a szemetes környezet önálló befolyásoló erejét próbálták megvizsgálni. Graffiti-mentes környezetben 13\% vitte el a borítékot, míg szemetes lépcsőházban 25\% lopta el a pénzt. A többféle rendezetlenség egyidejű jelenléte tehát tovább erősíti a normasértő magatartást, mint azok önállóan. 


\section{RECENZIÓ}

\section{A kutatás tanulságai}

Keizer, Lindenberg, Steg és munkatársaik kutatása nem csupán alátámasztani látszik a törött ablakok elméletében megfogalmazott hipotézist, hanem árnyalja is az eredeti felvetést. A kutatás tanulságai szerint az egyik típusú rendezetlenség (disorder) látható jelenléte valóban hozzájárul a másik típusú normasértés elkövetéséhez.

Ezek a kihágások azonban nem csupán a szociális normák figyelmen kívül hagyását eredményezik, hanem kiterjednek a közösségi együttélés formális szabályainak megsértésére is. A szabályszegés látható jelenléte épp úgy ösztönzőleg hat a privát előírásokra (pl. üzletközpont, parkoló stb. tiltó táblája), mint a jogszabályi tiltások (pl. lopás büntetőjogi tényállása) megsértésére.

Ennek megfelelően a szerzők arra hívják fel a figyelmet, hogy a közösségi normák megszegésének korai felismerése és a hatékony beavatkozás kulcsfontosságú

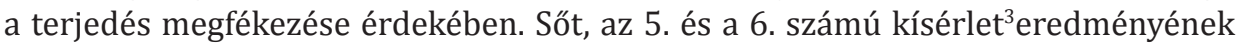
szellemében kijelentheto, hogy „kiterjedt rendezetlenség” esetében nem elégséges csupán „a törött ablakokat” rendbe hozni, hanem hathatós beavatkozással az összes nem megfelelő környezeti tényezőt egyszerre szükséges korrigálni.

\section{Néhány kritikai észrevétel}

Az ismertetett vizsgálat meggyőző eredményekkel zárult,ám az elmélet az elszegényedő városrészek nehézségeinek kezelésére csak korlátozottan alkalmas. A „törött ablakok elmélete” és az abból kifejlődő,zéró tolerancia” típusú rendészeti politikák fő vonzereje abban rejlik, hogy azonnali eredményeket ígér a bűnözés visszaszorítására (Sárosi 2008). A középosztály érdekeihez igazított modellel azonban óvatosan kell bánni. A zéró tolerancia közvetlenül reflektál a média és az általa formált közvélemény olykor elnagyolt és előítéletes igényeire. A valós problémák orvoslása helyett látványos rendészeti akciókkal és intenzív rendőri jelenléttel garantálja a lakosság szubjektív biztonságérzetét.

A rendészeti intézkedések célkeresztjébe kerülő marginalizált csoportok helyzete a középosztálynak szánt „hangulatjavító intézkedésekkel” nem változik érdemben. Ez a megközelítés gyakran a bűnözőkről kialakított előítéleteknek leginkább megfelelő személyeket száműzi a nyilvános terekből (Sárosi 2008). A hajléktalanokat, szerfüggőket, szexmunkásokat és az etnikai kisebbségekhez tartozó fiatalokat a segítség valós lehetősége nélkül kényszeríti rejtőzködésre. A normakövetési hajlandóságot látszólag megerősíti, ám a mögöttes okokat elfedi, a szociális gondokat más kerületekbe exportálja.

${ }^{3}$ A borítékban található pénz ellopását többen kísérlik meg, ha a boríték kihelyezése szemetes és graffitis környezetben történik, mintha csak az egyik zavaró tényező állna fenn. 


\section{RECENZIÓ}

Bár az agresszív rendőri fellépés bizonyos bűncselekménytípusok esetén visszatartó erővel bír, a komolyabb jogsértéseket csekély mértékben befolyásolja. A közrendzavarások előfordulása és a súlyosabb bűncselekmények számának alakulása között nem mutatható ki kauzális kapcsolat (Harcourt 2001, Sampson - Raudenbush 1999). A vandalizmus és a garázdaság megvalósítói nem feltétlenül azonosak a rablások és betörések professzionális elkövetőivel.

A „törött ablakok elméletének” legnagyobb veszélye, hogy tudományos hátteret és meggyőzőnek tűnő empirikus bizonyítékokat vonultat fel az állami beavatkozás határainak kitolásához. Eközben azonban leveszi a döntéshozók válláról a szociális gondoskodás és a strukturális problémák megoldásával kapcsolatos terhet. A rendteremtés ígéretével fellépő politika szélsőséges esetben az élhetőbb környezet létrehozása helyett a szegénység és kirekesztettség stigmatizálásához vezethet.

\section{Irodalom}

Kelling, G. L. - Wilson, J. Q. (1982): Broken windows: the police and neighborhood safety. Atlantic Monthly.http://www.theatlantic.com/magazine/ archive/1982/03/brokenwindows/4465/?single_page=true (Utolsó letöltés: 2018.01.06)

Harcourt, B. (2001): Illusion of Order: The false promise of broken windows policing. Cambridge, Harvard University Press

Robert, J. S. - Stephen, W. R. (1999): Systematic Social Observation Of Public Spaces: A New Look at Disorder in Urban Neighborhoods. American Journal of Sociology, 105, 603-651. https://dash.harvard.edu/bitstream/handle/1/3226951/ sampson_systematicsocialobservation.pdf?sequence=2 (Utolsó letöltés: 2018.05. 13.)

Sárosi, P. (2008): „Zéró tolerancia”. Veszélyes illúziók a rend fenntartásáról. Beszélő, 13. évf., 3. sz. http://beszelo.c3.hu/cikkek/"zero-tolerancia" (Utolsó letöltés: 2018.05.13.) 